\title{
POLITICAL MACHINATIONS IN A RURAL COUNTY
}

\section{Graeme Smith}

A long-running discourse both within China and abroad castigates local leaders for corruption and a related tendency to implement central government policy selectively. ${ }^{1}$ The interesting question is how and why this takes place. ${ }^{2}$ What are the mechanisms and internal logic of corruption and selective implementation for local Party élites and the bureaucracy, and why does such behavior persist? ${ }^{3}$ A previous debate on the origins of "selective policy implementation" involves questions of the central government's failure to reduce the "peasant burden" during the 1990s, and whether that indicated a loss of control over its local agents. ${ }^{4}$ This article examines corruption and selective policy implementation as

1 The first major instance of this practice of blaming local cadres, rather than central policies, occurred after the Great Leap Forward. See Xiaobo Lü, Cadres and Corruption: The Organizational Involution of the Chinese Communist Party (Stanford: Stanford University Press, 2000), pp. 98-106. A recent article goes further, arguing that "divided state power" has become a strategy for improving the CCP's resilience and legitimacy. While this is an intriguing thesis, the interpretation of causality is problematic. Cai Yongshun, "Power Structure and Regime Resilience: Contentious Politics in China", British Journal of Political Science, Vol. 38 (2008), pp. 411-32.

2 There is a considerable literature examining the operations of county-level governments, most notably A. Doak Barnett, Cadres, Bureaucracy, and Political Power in Communist China (New York: Columbia University Press, 1967) and Marc Blecher and Vivienne Shue, Tethered Deer: Government and Economy in a Chinese County (Stanford: Stanford University Press, 1996).

3 While it is difficult to construct a universal, cogent definition of what constitutes corruption, a persuasive set of criteria for when an action (or non-action) may be deemed corrupt is provided by Leslie Holmes, Rotten States? Corruption, Post-Communism and Neoliberalism (Durham: Duke University Press, 2006), p. 30. Of relevance are the criteria that it must be "carried out by actual or aspiring officials" and "perceived by significant sections of the population as corrupt".

4 See Kevin O'Brien and Lianjiang Li, "Selective Policy Implementation in Rural China", Comparative Politics, Vol. 31, No. 2 (1999), pp. 167-86; Thomas P. Bernstein and Xiaobo Lü, Taxation Without Representation in Rural China (Cambridge: Cambridge University Press, 2003); Maria Edin, "State Capacity and Local Agent Control in China: CCP Cadre Management from a Township Perspective", The China Quarterly, Vol. 173 (2003), pp. 35-52; and Linda Chelan Li, "Working for the Peasants? Strategic Interactions 
general phenomena, related to the configurations of political power and the behavior of key actors in a specific rural county, Benghai County of Anhui Province. ${ }^{5}$

In Benghai, ${ }^{6}$ the administrative system of Party control is a mercantile version of the political structure inherited from the Maoist era. Informal organizational norms relate to pre-existing networks of formal and informal political power. Thus, the game of governing is played "not on the ruins but with the ruins of Communism", ${ }^{7}$ as both higher-level and local governments redeploy available resources and time-tested political practices and norms in response to immediate practical dilemmas. The persistence of these practices, organizational forms and social ties can be a source of corruption and delegitimization for the local state, but they are also a source of assets and resources, and a basis for coordinated actions when the local state chooses to implement the policies of higher levels of government.

These traditional norms of governing and the centre-local dynamic which they entail shape patterns of selective policy implementation. They lead to a situation in which the county government only takes up initiatives wholeheartedly when three conditions are met:

1. the initiative is important to the annual assessment system, which (as described below) influences the priorities of the leading cadres;

2. the initiative raises revenue, either through levying fines, taxes or service fees, or by opening up revenue sources from higher levels;

3. the initiative benefits individual cadres and the "shadow state" financially. ${ }^{8}$

and Unintended Consequences in Chinese Rural Tax Reform”, The China Journal, No. 57 (January 2007), pp. 89-106.

5 Due to the need to protect sources, Benghai is a pseudonym. The county is located in central China and GDP per capita in 2009 was slightly higher than the provincial average. Benghai ranks in the top five in the province in terms of government revenues, meaning that the county government is in a position to provide services to rural residents, if it chooses to do so. Industrial output accounted for nearly two-thirds of GDP by the year 2000. This shift to an industry-centered economy means that the recent national abolition of agricultural taxes has not affected the income of the county government as seriously as it has in neighboring counties. When these taxes were abolished in 2004 they accounted for less than ten per cent of county government revenue.

6 Unger notes that "the performance of officialdom varies significantly across regions, dividing China into 'poor marginal agricultural regions', 'prosperous industrializing districts', and the 'agricultural heartlands". Benghai, despite being a "national-level impoverished county", largely exhibits the characteristics of the latter two categories. See Jonathan Unger, The Transformation of Rural China (Armonk: M. E. Sharpe, 2002), pp. 204-13.

7 David Stark, "Recombinant Property in East European Capitalism", American Journal of Sociology, Vol. 101, No. 4 (1996), p. 995.

8 Barbara Harriss-White, India Working: Essays on Society and Economy (Cambridge: Cambridge University Press, 2003). 
These patterns of selective policy implementation in turn reinforce traditional Communist governing practices and enhance the solidarity of existing nexuses of local power. This article begins with the holder of the highest level of de facto power, the county Party secretary, then examines the networks of formal and informal power around him, and outwards to an increasingly complex formal bureaucracy and the "shadow state" surrounding that. I examine the powerful bureaus controlling resources and personnel, down to the backwater bureaus, and discuss the circumstances of the county bureau's staff, both influential administrative cadres and ordinary personnel in service organizations.

My findings are based on observations and interviews with cadres, ordinary government workers, businesspeople and farmers in Benghai County over the period from 2004 to 2008. To further our understanding of how local government agencies operate in practice, I explore the nature of the political pressures exerted upon Party and government officials through the formal assessment system, and examine the interaction between the traditional Leninist levers of political control and commercial imperatives arising from the current local government "core task" (zhongxin gongzuo 中心工作) of attracting industrial investment. ${ }^{9}$ Finally, I explore the affirmation of traditional Communist norms - showcasing, output obsession, betting on the strong, and campaign-style governance - during the campaign to "construct a new socialist countryside".

\section{The Party Secretary: Ongoing Concentration of Power}

In Benghai, the county Party secretary effectively has the final say in all decisions involving personnel and the interpretation of central government policy. Provincial leaders colloquially refer to them as "the first productive force" (diyi shengchanli 第一生产力). While their formal power is considerable, prior cultivation of personal networks is essential both to securing the position and to wielding power effectively during their tenure. Benghai's current Party secretary previously served three years as the county head, allowing ample time to build up his networks. This has been the custom for most of Benghai's Party secretaries. Also, while the Party secretary hails from outside the county in accordance with the law of avoidance (huibi zhidu 回避制度), ${ }^{10}$ he was the deputy head of a larger neighboring county, so many subordinates are former classmates from the prefectural Party school. A further three-year posting to the central Party school has allowed him to extend his networks inside the prefectural, provincial and central levels of government, making it easier to

9 "Core tasks" are a common feature of Leninist mobilization campaigns. They denote assignments which override regular government work. See Kenneth Jowitt, New World Disorder: The Leninist Extinction (Berkeley: University of California Press, 1992), p. 56.

10 The principle that key posts must be held by non-local cadres applies to the county Party secretary and the county head, and for key posts such as the heads of the Organization and Finance Bureaus. 
access resources from higher levels. He also spent time working in Benghai at the township level during the 1980s.

The position of county Party secretary represents a career-defining opportunity, and the fates of Benghai's previous Party secretaries have been mixed. The most recent Party secretary did well, being promoted to deputy head of a powerful bureau in the provincial government. Others have been less successful, leading to the widespread belief that the county government was suffering from the poor fengshui of the county government building. ${ }^{11}$ This situation is being rectified, with more than 300 million yuan invested in a new county government headquarters on the other side of the valley. It will occupy a substantial area of land next to the industrial park and be fronted by a man-made lake (complete with "ecological islands"), thus conforming to ideal fengshui conditions: facing south over a body of water to a distant horizon of high peaks. $^{12}$

In Benghai, as elsewhere, a group of the key county leaders exert their influence by holding multiple posts. They hold leadership positions in the four leading groups (sitao banzi 四套班子): that is, the county Party committee, county government, the People's Congress and the People's Political Consultative Conference. Prior to 2002, the heads of the People's Congress and the People's Political Consultative Conference were usually old cadres with little or no political influence, in keeping with the relatively low status of these bodies. It was usually a requirement that the heads of these bodies had given up their positions in either the Party or the government. However, in 2003, the Benghai Party secretary broke that trend, concurrently assuming the position of head of the People's Congress. This is in keeping with province-wide and nationwide developments. $^{13}$ In 1990 and 1995, only five county Party secretaries in the province concurrently headed up the People's Congress, but by 2002 more than half held these dual positions; a year later in 2003, there were only five exceptions among Anhui's 61 county Party secretaries. The rationale was that, since both of these bodies are made up of local cadres, having the Party

11 Local governments spruiking the fengshui of industrial parks is noted in Ole Bruun, Fengshui in China: Geomantic Divination between State Orthodoxy and Popular Religion (Copenhagen: NIAS Press, 2003), pp. 157-58.

12 This project was stalled for over a year by a group of retired cadres. Facing the demolition of their houses, they successfully petitioned the provincial government to intervene on the grounds that it was a "vanity project". The old cadres were rehoused and, with the central government giving the green light to massive infrastructure spending in late 2008, this vanity project is back in favor with the provincial government. Provincial governments have earmarked projects worth 29 trillion yuan for inclusion in the central government's stimulus package. See "White Elephant Projects a Waste of Stimulus Cash", South China Morning Post (3 February 2009).

13 Dali Yang, Remaking the Chinese Leviathan: Market Transition and the Politics of Governance in China (Stanford: Stanford University Press, 2004), Chapter 8. 
secretaries (who are always from outside the county) head these bodies was an expedient way to enhance Party control and legitimacy, ${ }^{14}$ and to silence dissent from outspoken People's Congresses.

Control of personnel decisions by county Party secretaries is not unique to Benghai - and structural corruption often results. ${ }^{15}$ In one compilation of criminal cases involving county Party secretaries, ${ }^{16}$ the former Party secretary of Mengcheng County, Anhui, explained why involvement in corruption was unavoidable:

Too much power is vested in the "first-in-command" (yi ba shou一把 手). If I'm the county Party secretary, and I recommend someone for a post, will that carry the same weight as another county leader? I'm the Party secretary, so all candidates who've been recommended or who are seeking posts will come knocking. Whatever I say, the Party Organization Bureau will obey. Procedures are there in name only. Lines of authority that are there on paper don't exist. These problems are systemic. $^{17}$

Below the Party secretary, the crucial body for day-to-day decision-making is the standing committee of the Communist Party. Leading county cadres and the heads of the three most powerful Party organs (the Party Organization Bureau, the Propaganda Bureau and the Party Discipline Committee) sit on the Party standing committee (see Table 1), which meets at least once a month to discuss all matters relating to the county, particularly in regard to key personnel decisions. Only two township Party secretaries hold positions on the county Party standing committee.

The Xuanyang Party secretary partly owes his position on the committee to his close friendship with the county Party secretary, his high school classmate. The Xiaozi Party secretary was promoted after her competent performance when Xiaozi was hit by floods in 2005. In addition to personal factors, the special status of these township Party secretaries is also due to the strategic importance of their townships. Xuanyang houses the county seat, and Xiaozi is home to some of Benghai's most profitable industries. This is line with previous researchers' findings that the CCP takes great care to control strategically important local leaders by bringing them into higher levels of the Party-state. ${ }^{18}$

14 Bringing local People's Congresses to heel is more difficult in wealthier regions. See Oscar Almén, "Authoritarianism Constrained: The Role of Local People's Congresses in China" (PhD dissertation, Göteborg University, 2005).

15 There is considerable local literature on the problems posed by the concentration of power in the hands of Party secretaries. See especially Jian Da, "Wei 'yi ba shou' ma shou shi zhan de fubai” (Corruption from Following the Leader's Example), Cai zhi (Intelligence) (2003), p. 55.

16 Chen Ge, Yi shou gai tian: 18 ming xianwei shuji kuadiao de jingshi (One Hand to Cover Heaven: 18 Cautionary Examples of Fallen County Party Secretaries) (Beijing: Xinhua Chubanshe, 2006).

17 Ibid., p. 39.

18 Maria Edin, "State Capacity and Local Agent Control", pp. 42-50. 
Table 1: Portfolios of Party Standing Committee Members, 2007

\begin{tabular}{|l|l|l|}
\hline Position and responsibilities & Xitong 系统 ${ }^{19}$ & Background \\
\hline $\begin{array}{l}\text { Party Secretary and head of the People's } \\
\text { Congress Standing Committee }\end{array}$ & Party & Adjoining county \\
\hline County head. Overall government work & Party & Prefecture \\
\hline $\begin{array}{l}\text { Deputy Party Secretary and Deputy Head } \\
\text { of Standing Committee }\end{array}$ & Party & Local \\
\hline $\begin{array}{l}\text { Head, Party Organization Bureau (zuzhi } \\
\text { bu 组织部) }\end{array}$ & Organization & Adjoining county \\
\hline $\begin{array}{l}\text { Head, Propaganda Bureau (xuanchuan bu } \\
\text { 宣传部) }\end{array}$ & $\begin{array}{l}\text { Propaganda and } \\
\text { education }\end{array}$ & $\begin{array}{l}\text { Adjoining county } \\
\text { (Prefectural Party } \\
\text { Civilization Office } \\
\text { head) }\end{array}$ \\
\hline $\begin{array}{l}\text { Head, Party Discipline Committee (jiwei } \\
\text { 纪委), Inspection Bureau (jiancha ju 检查 } \\
\text { 局) }\end{array}$ & $\begin{array}{l}\text { Political and legal } \\
\text { affairs }\end{array}$ & $\begin{array}{l}\text { Adjoining county } \\
\text { (Organization } \\
\text { Bureau head) }\end{array}$ \\
\hline $\begin{array}{l}\text { Deputy County Head and Deputy Head of } \\
\text { Standing Committee. Legal affairs, } \\
\text { finance, personnel, administrative } \\
\text { examinations and approvals }\end{array}$ & Finance and \\
\hline $\begin{array}{l}\text { Deputy County Head. Social security, } \\
\text { science and technology }\end{array}$ & $\begin{array}{l}\text { Finance and } \\
\text { economics }\end{array}$ & $\begin{array}{l}\text { Prefecture } \\
\text { Central Labor } \\
\text { Bureau }\end{array}$ \\
\hline $\begin{array}{l}\text { Deputy County Head. Head, Development } \\
\text { and Reform Committee, Political and } \\
\text { Legal Affairs Committee, Pricing Bureau }\end{array}$ & $\begin{array}{l}\text { Political and legal } \\
\text { affairs }\end{array}$ & $\begin{array}{l}\text { Province (mishu 秘 } \\
\text { 书) }\end{array}$ \\
\hline Xuanyang Town Party Secretary & Party & Local \\
\hline $\begin{array}{l}\text { Committee Head, People's Armed Police. } \\
\text { Militia and PLA }\end{array}$ & Military & Distant county \\
\hline $\begin{array}{l}\text { Xiaozi Town Party Secretary and Deputy } \\
\text { Head of People's Political Consultative } \\
\text { Conference }\end{array}$ & Party; organization & $\begin{array}{l}\text { Local (Party } \\
\text { Organization } \\
\text { Bureau staffer) }\end{array}$ \\
\hline $\begin{array}{l}\text { Deputy County Head. Agriculture, } \\
\text { forestry, family planning, and health }\end{array}$ & $\begin{array}{l}\text { Prefectural } \\
\text { Personnel Bureau }\end{array}$ \\
\hline
\end{tabular}

Source: Benghai Government Website, 2007; author's interviews 2004-08.

\section{Deputies: An Expensive Habit}

On paper, deputy county Party secretaries and deputy county heads belong to separate systems, the former to the Party and the latter to the government. In

19 Xitong can be roughly translated as "functional portfolio", and refers to an official's primary area of responsibility. More powerful leaders, particularly the county Party secretary, effectively have a say in all portfolios. Kenneth Lieberthal, Governing China: From Revolution Through Reform, 2nd ed. (New York: W. W. Norton \& Co., 2004), pp. 218-33. 
practice, deputies are all seen as representatives of the Party. In addition to the five deputies on the county Party standing committee, there are a further six deputies without seats. One county official saw the large number of deputies as indicative of lavish government spending, wryly noting, "This means our county is rather like a rich playboy; it can afford lots of wives". The portfolios and bureaucratic affiliations (xitong) of the six lower-ranking deputies are shown in Table 2 .

Of these deputies, four were “sent down" (gua zhi 挂职) from higher levels of government (one from the central government, two from the province and one from the prefecture). Due to pressures to streamline higher levels of government, the prefectural and provincial governments had dispatched them and a large number of other staff to work in the county. In turn, counties and townships send their surplus cadres to the villages as a way of keeping an eye on village cadres. Thus, higher levels oblige lower levels to pad their own payrolls.

\section{Table 2: Portfolios of Lower-Ranking County Leaders}

\begin{tabular}{|l|l|l|}
\hline Position and responsibilities & $\begin{array}{l}\text { Main portfolio } \\
\text { (xitong) }\end{array}$ & Background \\
\hline $\begin{array}{l}\text { Land management, transport, } \\
\text { construction, social stability } \\
\text { (petitions) }\end{array}$ & $\begin{array}{l}\text { Finance and economics; } \\
\text { military }\end{array}$ & $\begin{array}{l}\text { Local (township leader, } \\
\text { head of Construction, } \\
\text { Environmental } \\
\text { Protection Bureaus) }\end{array}$ \\
\hline $\begin{array}{l}\text { Industry, attracting investment, } \\
\text { environmental protection, } \\
\text { statistics }\end{array}$ & Finance and economics & Local (mishu) \\
\hline $\begin{array}{l}\text { Commerce, grain, supply and } \\
\text { marketing cooperatives }\end{array}$ & Finance and economics & $\begin{array}{l}\text { Local (deputy head, } \\
\text { county Agricultural } \\
\text { Committee) }\end{array}$ \\
\hline $\begin{array}{l}\text { Tourism, electronic } \\
\text { governance, economic } \\
\text { information }\end{array}$ & Finance and economics & Prefectural government \\
\hline Poverty alleviation, civil affairs & Finance and economics & $\begin{array}{l}\text { Provincial Records } \\
\text { Bureau }\end{array}$ \\
\hline $\begin{array}{l}\text { Education, culture, } \\
\text { broadcasting, sport }\end{array}$ & $\begin{array}{l}\text { Propaganda and } \\
\text { education }\end{array}$ & Neighboring county \\
\hline
\end{tabular}

Sources: Benghai Government Website, 2007; author's interviews, 2004-08.

All of the deputy heads are assigned a range of portfolios. With a larger number of deputies, the likelihood of bureaucratic overlap and squabbling over

20 Later subject to extralegal detention (shuanggui), and eventually convicted on corruption charges, see below. 
resources and staff increases, particularly in the finance and economic xitong, which boasts eight deputies. The deputies outrank the heads of the bureaus that they are charged with overseeing, and the bureau heads spend a good deal of time petitioning the deputies for information and access to resources. However, in the case of a powerful county bureau, such as Finance, the bureau head may have greater clout, particularly if the deputy hails from outside the county. Another crucial variable is how seriously the deputies take their work. Many deputies are notorious for appearing only when a free meal is on offer.

Such a proliferation of posts can also have unexpected consequences. As a staffer at the county television station said:

When there are too many deputy county leaders, it's a pain. Everyone wants their say, so meetings drag on interminably. There are so many cadres at the main table, you don't know where to point your lens. Some senior deputies work out how long the camera lingers on them, and if they get eight seconds less than the cadre below them in the pecking order, they'll never forgive you. They even come and make trouble at the television station!

Because seating arrangements reflect rank, and rank reflects power, secret or open conflicts over seating are impossible to avoid. There's also a lot of uncertainty over who is responsible for what. If there's an accomplishment, they'll all want it; if there's a problem, it's someone else's fault. There's a lot of attention paid to outward signs of statustheir office has to be at least as big [as other deputies], their cars have to have the same luxuries, their computers have to be at least as expensive - otherwise they'll see it as a grave injustice.

This proliferation of deputies has occurred despite a 2006 campaign called the "three reductions" (san jian 三减) to reduce the number of deputy Party and government positions at all levels of local government. Such a large number of deputies cannot be effectively supervised, particularly when they hail from different administrative levels and xitong, and in 2007 one of the deputies listed in Table 2 was caught with his hand in the till.

The deputy Party secretary responsible for land management, transport and construction (who had been working in collaboration with the deputy head of the construction bureau) was placed under house arrest (shuanggui 双规) by the discipline inspection committee for over a year, ${ }^{21}$ and eventually sentenced to 15 years in jail for receiving over two million yuan in cash and gifts from construction companies, in exchange for approving projects and waiving land transfer payments. The sum involved is believed by county residents to be higher. During a 2008 visit, I overheard children singing a ditty about the adventures of "50-million-yuan Zhang" (Zhang ban yi 张半亿). An official involved in the investigation revealed that extracting information from local witnesses was

21 This exceeds the six-month limit for extra-legal detention. See Flora Sapio, "Shuanggui and Extralegal Detention in China", China Information, Vol. 22 (2008), p. 15. 
difficult. He explained, "Keep them awake, and rough them up all you like, but they won't talk. They have to do business here. It's where their networks are. If they talk, no one will trust them again." Because other county leaders are implicated, no property developers involved faced criminal sanctions, but they were required to make "contributions". Informal Party procedures continue to trump the government's formal justice system. ${ }^{22}$

\section{Informal Players and the Shadow State}

The root of much "embedded corruption" 23 in Benghai has been the emergence of the Party secretary's personal secretaries (mishu) as a force in county politics. ${ }^{24}$ Much of their influence arises from the blurred definition of their powers, leading to them being referred to as "Chiefs of the Bureau with No Accountability" (buguan bu buzhang 不管部部长). ${ }^{25}$ Their power derives from managing information flows and access to the Party secretary. ${ }^{26}$ By controlling information flows they develop clientelist networks, and can do much to influence the agenda of the county government. In recent years, the Party secretary is often out of the county, seeking to attract investment or attending meetings at the provincial or prefectural level, leaving much of the day-to-day work - and opportunities for personal enrichment - to their personal assistants.

A crucial factor is the extended tenure of the personal secretaries. They are all natives of Benghai, and in some cases have spent decades building up connections inside and outside the county. On arrival, a new county leader becomes to a large extent dependent on personal assistants to decide whom they can work with, and whom not. One county official claims to have heard a secretary boast, "What does a county head amount to? In a few years he'll be gone. I'll still be here." In the event that a personal secretary leaves the county government compound, he (none are female) is usually transferred to a post of

22 See also Melanie Manion, Corruption by Design: Building Clean Government in Mainland China and Hong Kong (Cambridge MA: Harvard University Press, 2004), pp. 128-40.

23 Thomas P. Bernstein and Xiaobo Lü, Taxation Without Representation, pp. 109-14.

24 The influence of corrupt personal assistants at the centre has long been noted, see Kenneth Lieberthal, Governing China, pp. 212-15. Chen Xitong's secretary, Chen Jian, provides a recent example of personal assistants acquiring influence in Beijing, but little has been written on their role in sub-provincial politics.

25 Zhang Peiyuan, "Mofei you lundao mishuzhang 'luoma'?" (Could it be Time for Personal Assistants to "Fall off the Horse"?), Gongren ribao (Worker's Daily), 12 December 2005. This article lists a string of corruption cases involving personal assistants, from wealthy coastal regions to poorer inland areas.

26 Although it is a sensitive topic, an occasional article outlining this phenomenon does appear in the mainland press. See Zhang Jianwen, "Xinxi yu mishu fubai" (Information and the Corruption of Personal Assistants), Guanming ribao (Guanming Daily), 23 November 2005. 
county branch department head, or assigned as a township head or township Party secretary. ${ }^{27}$ While it is unusual for personal secretaries to buy their position, they pay regular bribes to protect it, a practice which heads of profitable bureaus also engage in.

Another type of personal assistant to enjoy status and rent-seeking opportunities well beyond their actual position are the chauffeurs of leading cadres. Chauffeurs joke that they spend more time with leading cadres than the cadres' wives do, and consequently they know everything. One driver, aged in his late thirties, has already managed to accumulate three houses in the county seat. Another driver is the subject of an ongoing petition to higher authorities. After banqueting with his township Party secretary (and former county police chief) in the county seat, he returned to his township late in the evening. He was so inebriated that he did not realize he had struck and killed a pedestrian. When the matter came to light, the Party secretary denied that the chauffeur had touched a drop. The matter remains unresolved. ${ }^{28}$

An indication of the influence of personal assistants came on 10 August 2005, when the Anhui provincial government issued an edict, directed at provincial, prefectural and county governments, entitled "Provisional Legislation Concerning the Strengthening of the Management and Supervision of Leading Cadres' Personal Assistants". ${ }^{29}$ The circular listed 17 actions that were forbidden and should result in instant dismissal. Among the more notable were prohibitions against "using one's position or using the name of leading cadres for making arrangements to the benefit of friends, relatives, or themselves"; "interfering in personnel issues, particularly arranging the selling of posts for others or oneself"; "deliberately providing leading cadres with false reports, statistics, or hushing up incidents"; "encouraging grass-roots or leading cadres to arrange illegal entertainment"; "receiving money, shares, or valuable gifts on behalf of leading cadres"; and "seeking illegal benefits for leading cadres, their spouses, children and other relatives".

27 The increasing influence of mishu at the county level is paralleled at the township level by the growing influence of Office Managers (bangongshi zhuren), who control access to township Party secretaries. In one township where government offices were generally deserted, the office manager had eight staff working under him, and even had his own car.

28 One Chinese writer notes similar behavior from personal assistants and drivers, where one driver in Henan accumulated two million yuan. Jiang Zengpei, Tanguan de siji yu mishu (The Drivers and Personal Secretaries of Corrupt Officials), 18 December 2006 (cited 17 March 2007). Available from: http://pinglun.eastday.com/eastday/news/node47824/node95768/ node95843/node95845/node97831/index.html, last accessed 17 March 2007.

29 "Anhui quxiao sheng xia shi xian lingdao zhuanzhi mishu" (Anhui Province Abolishes Fulltime Personal Assistants for Prefectural and County Leaders), Zhongguo qingnian bao (China Youth Daily) (2005), http://zqb.cyol.com/gb/zqb/2005-08/13/content 48279.htm, accessed 18 May 2009. 
Along with drivers and personal assistants, the friends and relatives of leading cadres make up a "shadow state" around the formal state bureaucracy. Barbara Harriss-White defines the shadow state as a "set of intermediaries who ensure that the informal economy is supplied cheaply with goods, rights or favors from the State (or who simply steal them), and who can sell goods and services to the State at higher prices than would be the case in an 'open' market". ${ }^{30}$ The concept of "shadow state" is more nuanced than emotive descriptions of local state corruption, such as "gangster capitalism", 31 which exaggerate the overt violence of the local state, and fail to capture the banal reality that many ordinary citizens, when the opportunity arises, engage in "primitive accumulation" by pilfering from the state. ${ }^{32}$

In Benghai, close friends and relatives of officials run businesses that contract goods or services to the local state, varying from small restaurants, printing shops and car repair yards to large construction and property development firms. Sometimes these firms are specific to particular bureaussuch as relatives of Forestry Bureau cadres who own seedling nurseries. Having firms run by friends and relatives reduces the risk of petty corruption for government officials. A cut of around 20 per cent will be taken by the gatekeeper who purchases goods or services from these firms, either up front as cash, or later as a gift. Aside from the economic costs of inflated prices paid for substandard goods and services, the shadow state also exacerbates inequality by acting as an informal barrier to ordinary rural residents who wish to engage in private entrepreneurship. This partly explains why rural residents opt for laboring jobs in urban areas rather than engaging locally in business, even though the returns to the latter have been improving, while returns to labor have declined sharply. ${ }^{33}$

\section{The Bureaucracy: Money and Personnel}

While Benghai County has seen substantial cuts in the number of township and village government personnel since 2001, the proliferation of bureaus at the county level in recent years is stunning - at one stage in my research it appeared that there was a new office opening each week. Some are related to specific projects, such as the Eco-Industrial Area Management Committee (shengtai

\footnotetext{
30 Barbara Harriss-White, India Working, p. 81.

31 Kathy Le Mons Walker, “'Gangster Capitalism' and Peasant Protest in China: The Last Twenty Years", Journal of Peasant Studies, Vol. 33, No. 1 (2006), pp. 1-33.

32 See, for example, an account of villagers colluding with cadres to embezzle poverty alleviation funds. Tan Tongxue and Liu Qin, “Pao fupin' guocheng zhong de guanliao luoji yu siren wangluo" (The Role of Bureaucratic Logic and Private Networks in Chasing Poverty Alleviation Funds), Sannong Zhongguo (Rural China), No. 3 (2006), pp. 132-39.

33 See Huang Yasheng, Capitalism with Chinese Characteristics: Entrepreneurship and the State (Cambridge: Cambridge University Press, 2008), pp. 123-24.
} 
gongye qu guan weihui 生态工业区管委会) or specific products that the county government deems worthy of promotion, such as the Tea Development Office (chaye fazhan bangongshi 茶叶发展办公室), or reflect policy thrusts at higher levels of government, such as the Development and Reform Committee (fazhan he gaige weiyuanhui 发展和改革委员会) to carry out the instructions of the National Development and Reform Commission. Each new office and committee is an opportunity for friends and relatives to join the county payroll.

Bureaucratic power at the county level and below boils down to control over personnel (ren 人) and finances (cai 财). Bureaus can be divided into those with control over personnel and hence resources (chess players); those with access to resources or funding (big earners); and those with neither power nor money (backwaters). ${ }^{34}$

\section{The Chess Players}

When asked to nominate the most corrupt bureau, the head of a middle-ranking county bureau laughed, "Are you serious? Do your really need to ask that? It's no contest. The Party's Organization Bureau is the most corrupt." While the county Party secretary has the final say in key appointments to the bureaus under his jurisdiction, ${ }^{35}$ the county government has expanded to such an extent that the Organization Bureau (zuzhi bu 组织部) wields considerable power. ${ }^{36}$ Ostensibly, the government's Personnel Bureau (renshi bu 人事部) is responsible for all government appointments below the rank of county department head but, in reality, the Party's Organization Bureau has a major say in any appointment above the rank of tea lady. The head of the Personnel Bureau is always the deputy Party secretary of the Organization Bureau, a clear indication of their relative importance. Effectively, the Personnel Bureau serves as an extension of the Organization Bureau. At the same time, the county-level Party Organization Bureau has considerable autonomy vis-à-vis higher levels, as its relationship with the prefectural Party Organization Bureau is one of "professional relations" (yewu guanxi 业务关系), rather than restrictive "leadership relations" (lingdao guanxi 领导关系). A consequence of the Organization Bureau's sway is that the county Party secretary and Party standing committee can readily influence all government appointments within the county.

34 Ben Hillman's study of local government in Yunnan similarly divides government bureaus into four categories: "Big budget", "engaged with the private sector", "quiet earners" and "veto players". See Ben Hillman, "Politics and Power in China: Stratagems and Spoils in a Rural County" (PhD dissertation, The Australian National University, 2005), pp. 141-48.

35 The prefectural and provincial levels directly control an increasing number of bureaus. Banks, taxation bureaus, insurance companies and tobacco bureaus all answer to higher levels.

36 The crucial role of the Organization Bureau in local government is a notable continuity from the Maoist era. See especially A. Doak Barnett, Cadres, Bureaucracy, and Political Power, pp. 181-83. 
The revival of the practice of selling positions (mai guan 卖官) has received considerable attention in the Chinese media in recent years. The Organization Bureau, in conjunction with the county Party secretary, is at the center of this lucrative practice. The key to its persistence is the amount of authority vested in a handful of officials, but counter-intuitively "the buying and selling of positions" is often advanced as a reason for stalling on the expansion of democratic reforms. ${ }^{37}$

Local sources suggest that about 80 per cent of the department-head posts in Benghai are bought, ${ }^{38}$ but interviewees are at pains to point out that it is not a simple commercial transaction. The candidate for the post must be capable of doing the job (a large proportion of mai guan transactions involve transfers within the same agency), and must be trusted by both the Party secretary and the Organization Bureau. This transaction is a mixture of what James Scott has termed "parochial corruption", where kinship and personal connections determine access to power, and "market corruption", where those who can pay the most gain access to political resources. ${ }^{39}$

The transaction is seldom direct, and many informants complained about the time-consuming process of "looking for a contact" (zhao ren 找人) to handle it. Securing one's position is not simply a matter of handing over the cash. To avoid potential charges of bribery, there are games of mahjong between the spouses of the relevant actors where the applicant's wife has a deliberate bad run of luck; department store cards arrive in red packets; overpriced tea is purchased from a retailer recommended by the contact; useful intermediaries are banqueted; and trust-building visits to saunas or massage parlors smooth the deal.

The amounts involved and the scope of the problem are not trivial. As one informant in Benghai put it, "Everyone is doing it. The only difference between now and the Qing dynasty is that back then the selling of positions was out in the open. If someone gets caught, they've either been isolated in a factional struggle, or they got too greedy and kept too much for themselves." The Party secretary of Dingyuan County, in central Anhui, took 334 bribes during his time in office, totaling 2.84 million yuan. ${ }^{40}$ Of these bribes, 297 were instances of receiving money for bought positions (others related to construction projects). It emerged that all 37 township heads had purchased their posts. The Organization Bureau head, the Party secretary's chief accomplice, was sentenced to 13 years in jail.

37 See comments from Li Junru, Vice President of the Central Party School, Reuters: "Beijing Anxious to Avoid Chaos of Political Reforms", South China Morning Post, Hong Kong, 11 March 2006.

38 Other researchers concur that the buying and selling of positions is "widespread and severe". See Li Lianjiang, "Direct Township Elections", in Elizabeth J. Perry and Merle Goldman (eds), Grassroots Political Reform in Contemporary China (Cambridge MA: Harvard University Press, 2007), p. 116.

39 James C. Scott, Comparative Political Corruption (Englewood Cliffs: Prentice-Hall, 1972).

40 Shi Fei, "Fubai shuji mai guan, zuzhi bumen yao fuze" (If a Corrupt Party Secretary Sells Positions, the Organization Bureau Is Responsible), Xinhua, 21 October 2006. 
Attempting to list the different bureaus in Benghai County according to influence would be tedious, but recent cases of selling government positions provide evidence about the relative power of different county institutions. In Henan Province's Shangcai County, the position of head of the Finance Bureau attracted a top bid of 400,000 yuan, the position of director of the county hospital attracted a payment of 300,000 yuan, while township Party secretary positions went relatively cheaply, for between 60,000 and 100,000 yuan. Table 3 details payments made from 2000 to 2005 for the purchase of various positions in rural Shangzhou Prefecture, Shaanxi.

Table 3: Payments for Positions in Shangzhou District, Shaanxi

\begin{tabular}{|c|c|c|}
\hline Original Position & Purchased Position & $\begin{array}{l}\text { Payment } \\
\text { (yuan) }\end{array}$ \\
\hline $\begin{array}{l}\text { Deputy Party secretary, discipline } \\
\text { inspection committee }\end{array}$ & Head, education bureau & 380,000 \\
\hline Head, city government office & $\begin{array}{l}\text { Assistant to head of neighboring } \\
\text { county }\end{array}$ & 50,000 \\
\hline Deputy head, transport bureau & $\begin{array}{l}\text { Deputy head, government office; } \\
\text { Deputy director, office for } \\
\text { supervising freeway land } \\
\text { requisition }\end{array}$ & 50,000 \\
\hline Deputy head, finance bureau & Head, same bureau & 50,000 \\
\hline Township Party secretary & Head, family planning office & 50,000 \\
\hline Deputy head, taxation bureau & Head, same bureau & 40,000 \\
\hline $\begin{array}{l}\text { Director, district tourism company; } \\
\text { deputy township head }\end{array}$ & $\begin{array}{l}\text { Head, external affairs section, } \\
\text { tourism bureau }\end{array}$ & 30,000 \\
\hline $\begin{array}{l}\text { Deputy head, office of district } \\
\text { government in the provincial seat }\end{array}$ & Head, Party committee office & 30,000 \\
\hline Staff, rural workers' bureau & Deputy head, same bureau & 26,000 \\
\hline Deputy head, organization bureau & $\begin{array}{l}\text { Head, personnel and labor } \\
\text { bureau }\end{array}$ & 20,000 \\
\hline $\begin{array}{l}\text { Deputy head, poverty alleviation and } \\
\text { development bureau }\end{array}$ & Head, same bureau & 20,000 \\
\hline $\begin{array}{l}\text { Deputy head, law enforcement } \\
\text { section of family planning office }\end{array}$ & Head, same bureau & 20,000 \\
\hline Township Party secretary & Head, forestry bureau & 10,000 \\
\hline
\end{tabular}

Source: China Elections Website www.chinaelections.org/NewsInfo.asp?NewsID=93206, accessed 21 October 2006.

Other offices whose power largely derives from control over people rather than resources include the Propaganda Bureau (xuanchuan bu), the Party Discipline Committee (jiwei) and the County Party Committee Office (xianwei ban). 


\section{The Big Earners}

A number of bureaus fall into this category, particularly in a county such as Benghai where government revenues are healthy. The biggest earners are those with the capacity to raise funds from businessmen, ordinary residents and other bureaus. The Finance Bureau (caizheng ju 财政局), the Taxation Bureau (shuiwu ju 税务局), the Construction Bureau (jianshe ju 建设局), the Transport Bureau (jiaotong ju 交通局), the Land and Resources Bureau (guo tu ziyuan ju 国土资源局) and various law enforcement agencies are all big earners.

Despite edicts prohibiting waste, wealthier bureaus flaunt their wealth through cars, mahjong gambling and banqueting. One informant with access to expenditure records estimated that the county Taxation Bureau alone spent 700,000 yuan annually on banqueting, which worked out at approximately 30 yuan per staff member per day. Due to the nature of the tax bureau's work, its members were often treated to lunch and dinner by businesspeople and other bureaus, so the informant reckoned that the amount spent on their culinary pleasure would be higher-closer to two million yuan. Employees of the Finance Bureau derive income through their discretionary control over the budgets of township governments and other county bureaus. A bagman for an impoverished bureau, returning from an after-hours visit to the Finance Bureau offices, complained, "What can you do? If you don't pay up, they'll allocate the funds to another bureau. You have to pay up."

The head of the village adjoining the county seat has amassed a fortune by combining all the entertainment needs of officials and businessmen under one roof, a short walk from the county government headquarters. Sauna City offers a hot-pot restaurant, gambling rooms, saunas and prostitutes, usually sampled in that order. Many bureau chiefs and county staff seeking promotion grumbled about excessive eating, drinking and other activities loosely classified as "fun" (wan'r 玩儿), but most felt they had no choice but to join in.

An excellent measure of the relative power of different bureaus is the number and make of vehicles that they have at their disposal. The charity with which I worked, which was designated as a "unit directly under the county government" (zhishu danwei 直属单位), formerly had one vehicle, left over from a previous project. Because it was an up-market, fully-imported SUV, it was in great demand with the county government, and the county Party secretary in particular. As a direct result of our unit's low position in the pecking order, we provided the vehicle, which was expensive to fuel and maintain, free of charge to him. After salaries, this was our organization's main expense (the vehicle was sold when the Party secretary stepped down in 2006.) The county Party branch has the largest fleet of cars, followed by the finance and tax bureaus. Even the humble Civil Affairs Bureau has four new vehicles, the most luxurious costing a staggering 180,000 yuan (about US\$26,380). Reflecting their lower status, most township governments have only one vehicle for the use of officials. Yan Sun 
estimates that the money squandered on the public funding of automobiles is trumped only by banqueting. ${ }^{41}$

The wealthiest office in Benghai, surprisingly, had no capacity to levy fees, impose fines or arrange personnel appointments. The office had been set up to manage the construction of an upstream extension to an existing hydroelectric dam. Part of its largesse derived from siphoning off earmarked funding for the project, but the greatest windfall was from kickbacks paid by construction contractors hoping to win the rights to build the dam.

\section{The Backwaters}

Locals refer to such bureaus as “impoverished yamen” (qing shui yamen 清水衙门). With access to neither resources nor influence, posts in these bureaus are the least sought after, although they usually do have the advantage of being under less administrative pressure than other bureaus. As one finance bureau staffer said of the county agricultural extension centre, "I wouldn't mind a job there. They've got no tasks (renwu 任务) to fulfill. They come and go as they please!" Other examples of backwater county bureaus include the Records Bureau (dang'an ju 档案局), the Party History Research Office (dang shi yanjiushi 党史 研究室) and the Cultural Affairs Bureau (wenhua ju 文化局).

The least desirable bureaus in this category are those with few resources or influence, but considerable administrative pressures from above. Perhaps the most onerous is the Letters and Visits Bureau (xinfang $j u$ 信访局), which is charged with mediating disputes (usually over land requisitioning), with practically no resources other than the power of persuasion. Ongoing disputes with aggrieved groups of county residents affect the political prospects (zheng ji 政绩) of county, township and village leaders, so the pressure brought to bear on this under-funded bureau is considerable. To complicate matters, the local leaders themselves are frequently the cause of the grievances, placing the bureau in a nearly untenable position. This was borne out recently in Benghai County when the head of the Letters and Visits Bureau took his own life, leaving a note attributing his suicide to his inability to do his job.

A bureau may leave the backwaters category when changes in central or provincial government policy lead to changes in its access to resources. For example, the county Labor Bureau (laodong ju 劳动局) was once largely responsible for industrial safety and the employment of manual workers in the township governments. Now it is the "Labor and Social Insurance Bureau" (laodong he shehui baozhang ju 劳动和社会保障局). Central government moves to start providing basic social insurance coverage for rural areas has led to significant resources being directed to this formerly-impoverished bureau, allowing it to hire new staff and regularly to host some of Benghai's most lavish

41 Yan Sun, Corruption and Market in Contemporary China (Ithaca: Cornell University Press, 2004), pp. 102-03. 
banquets. These are nearly always held in a restaurant run by the elder brother of the Labor Bureau chief. ${ }^{42}$

The Civil Affairs Bureau (minzheng $j u$ 民政局) and the Forestry Bureau (linye ju 林业局) have undergone similar transformations in recent years. The distribution of disaster relief funds means that the former now boasts an impressive fleet of imported vehicles, while forestry has thrived on Zhu Rongji's “returning the fields to forest" policy (tui geng huan lin 退耕还林), whereby farmers were subsidized for converting marginal sloping farmland into forest land. Initially, the funding was channeled through each level of the Forestry Bureau, allowing considerable scope for raking off the funds and employing new staff. At the peak of the windfall, one township Forestry Bureau employed over 30 staff, when it required at most half that number. Not all attempts to milk this project were successful, however. On the eve of the central government's launch of the program, large numbers of friends and relatives of Forestry Bureau employees set up seedling nurseries for the most common tree varietieschestnuts, maple trees and poplars. The result of this competition between employees' families was that many newly-established nurseries were unable to secure contracts.

\section{Staff}

Studies of local government in China tend to overlook a key dynamic, that staff working within the same bureaucratic system (or xitong) experience quite different status, incentives and career mobility, depending on whether they are classified as administrative staff (xingzheng ganbu 行政干部 or gongwuyuan 公务员), service staff (shiye ganbu 事业干部), off-budget personnel (bianzhi wai 编制外) or manual laborers (gongqin 公勤). ${ }^{43}$ Lumping all of these different types of workers together as "grass-roots officials" does not produce a sufficiently nuanced snapshot of local government.

\section{Administrative Staff}

At the county level, a high percentage of cadres belong to this category, while at the township level only leading Party cadres and the heads of various Party or government administrative organs (such as the Family Planning Office or the Taxation Bureau), enjoy this status. Administrative staff are classified by the central government as civil servants, and the Party Organization Bureau at the

\footnotetext{
42 Ben Hillman ("Politics and Power") surveyed the owners of five different restaurants to gauge the relative wealth of different bureaus. In Benghai this was less fruitful, due to the Balkanization of dining practices. Each bureau had its own preferred restaurant, run by relatives of a senior staffer.

43 Service organizations are government agencies without an administrative or profitmaking function. They include agencies involved in education, research, sport, health, culture and social welfare. See Kjeld Erik Brødsgaard, "Institutional Reform and the Bianzhi System in China", The China Quarterly, Vol. 170 (2002), pp. 361-86.
} 
level immediately above them in the hierarchy assigns them to their posts. Thus administrative cadres at township level are appointed by the county Organization Bureau. The salaries of administrative cadres are guaranteed in full by the Finance Bureau of the relevant level. Despite numerous streamlining campaigns targeting administrative cadres, landing such a job is still seen as a guarantee of lifetime employment.

The primary differences between service and administrative staff are status, security of tenure and career mobility. A recent county government document, explaining the allocation of new central funding under the "sunshine project" (yangguang gongcheng 阳光工程), ${ }^{44}$ consistently directs more funding to administrative personnel. While administrative personnel are allocated 2500 yuan per head for office expenses, those in service agencies receive only 1500 yuan. Transport costs of vehicles owned by administrative units are subsidized at 30,000 yuan each, while those parked in neighboring service agencies get 10,000 yuan less.

While it is easier to bring service staff onto the payroll, and the county government's revenue imperative is partly driven by pressure to keep friends and relatives on the books, ${ }^{45}$ service staff are among the first to lose their posts when the county government faces a streamlining campaign. An agricultural extension agent in Jiangxi, describing the streamlining reforms conducted in 2004 in his rural county, reported that the number of staff in service agencies decreased from 666 to 396 (a decrease of over 40 per cent) while the number of administrative cadres actually increased from 360 to $362 .^{46}$

\section{Service Staff}

The staff in "service organizations" (shiye danwei 事业单位) who rank below deputy section chief ( $f u$ keji 副科级) are appointed by the government Personnel Bureau, while the Party Organization Bureau assigns those above this rank. Their salaries depend on the status of their organization. Fully-funded service organizations pay their staff entirely from Finance Bureau monies; partially funded units (cha'e danwei 差额单位) pay their staff a portion of their salaries, while the rest must be raised through commercial activities or levying fees. ${ }^{47}$

44 Guanyu yinfa Benghai xian 2009 nian bumen yusuan bianzhi fang'an de tongzhi (Notification Concerning the Initiation of Budgetary Allocations to Benghai County Departments in 2009).

45 The principle of "first feed the staff, then build the government" (yi yao chifan, er yao jianshe 一要吃饭, 二要建设) is referred to as a "guiding principle" in government documents.

46 Li Changjin, "Nongji tuiguang zhi tong" (The Difficulties of Agricultural Technology Extension), Sannong Zhongguo, Vol. 8, No. 2 (2006), p. 137.

47 The funding situation of staff within the same bureau can be tremendously complex: it is common for staff of the same rank, working in the same office, to belong to completely different categories. Some may be fully-funded personnel, some partially-funded, some 
Other service organizations are entirely self-funded (zi shou zi zhi 自收自支). One might expect that self-funded units would be the least desirable, but the reverse is often the case. County hospitals are largely self-funded; the directors of these hospitals and their procurement agents benefit from service charges and kickbacks. $^{48}$

It is common for competent service staff to be drafted into more powerful administrative bureaus. During my research, the best-trained agricultural technician in Benghai spent most of his time working for the county Party Organization Bureau on government campaigns unrelated to agricultural extension. This system of temporary transfers by the Organization Bureau is a carry-over from Maoist times, ${ }^{49}$ and was widely viewed as undermining the professional capacity of service agencies. A county official lamented:

It's not as though the Organization Bureau is short of staff. It's just that all of the people who've managed to get onto their payroll are useless, or have no interest in doing their job. So, as a powerful bureau, they poach the most capable staff from other agencies. When they're finished, they'll just send them back. No matter how capable they are, without someone helping out behind the scenes (houtai 后台), there's no way onto the administrative cadre payroll.

In this case, employees are paid the salary of their original bureau, regardless of the actual work they are engaged in, or how long they have been with their new bureau. To transfer successfully across to the administrative cadre payroll, in addition to informal mechanisms, a period of study at Party school is required, and examinations must be sat.

An account from an agricultural extension worker from Hubei Province reveals the antipathy felt by some service personnel towards administrative cadres: ${ }^{50}$

Administrative cadres can elect to take early retirement, and always receive an old age pension. Agricultural technicians give the best years of their life to exhausting agricultural work, yet receive no support in retirement.

When administrative cadres lost their posts during streamlining reforms, they still got their salary, and when posts became vacant they could

entirely self-funded and others working "off budget". This gives rise to severe tensions among staff.

48 See also Kenneth J. DeWoskin and Ian J. Stones, "Facing the China Corruption Challenge", Far Eastern Economic Review, Vol. 169, No. 7 (2006), p. 37.

49 A. Doak Barnett, Cadres, Bureaucracy, and Political Power, pp. 58-60.

50 Nongjiyuan (An Agricultural Technician), "Ting dang de hua - cuo le ma? Yige jiceng nongjiyuan de xinsheng" (Were We Wrong to Obey the Party? Thoughts of a Grass-roots Agricultural Technician) (webpage), Zhongguo nongcun yanjiu wang (Chinese Rural Studies Website), 19 October 2005, http://www.ccrs.org.cn/article view.asp?ID=442, accessed 7 August 2006. 
apply for them. Yet when agricultural technicians lost out in streamlining reforms, they were just cleared from the books. What sort of reform is this?

Agricultural technicians are professionally trained, and their "quality" (suzhi 素质) is superior to administrative cadres drawn from the ranks of high school graduates and village cadres ... When I think back on my fellow students, who failed to gain admission to university but instead joined the civil service, one questions the value of university entrance exams ...

This supports Li Bobai and Andrew Walder's conclusion that early entry to the Party leads to an administrative post. ${ }^{51}$ It also contradicts earlier accounts of the leading role of technical specialists in county administration. ${ }^{52}$ Staff working in Benghai County's service agencies are often better qualified than administrative cadres and county leaders.

\section{Off-Budget Employees}

Off-budget (bianzhi wai) employees are appointed directly by their work unit, and as such are an appealing option for many bureau heads, because they have greater control over these staff members. They are also cheaper than personnel employed through the formal staffing system. One county-level cadre remarked, "There is a young staffer in my bureau who has been with us for about two years. He's very capable, and does twice as much work as anyone else, but for less than half the salary. It really isn't fair. But if he slacks off, the [bureau] boss will sack him the next day."

In many bureaus, formal staffing posts remain unfilled, while a large number of off-budget personnel are employed. As long as a bureau has available funds, it will take on staff, as there is constant pressure on bureau heads to take in new graduates and demobilized soldiers. The pressure from the friends and relatives of county government staff is particularly acute, and lack of oversight in the hiring of off-budget personnel can lead to absurd situations. In a neighboring county, the niece of the Tax Bureau chief was among the off-budget staff. This would be unremarkable news, except that she was still attending primary school.

While off-budget personnel are subject to less formal administrative control-for example, annual assessments (kaohe 考核)—many interviewees noted that their growing numbers make the county government resemble Qiang Zhongshu's metaphor for marriage: the besieged city (wei cheng 围城). Offbudget employees desperately want the security and conditions of a formal staff post, while many inside the formal staffing system feel trapped by administrative

\footnotetext{
$51 \quad$ Li Bobai and Andrew Walder, "Career Advancement and Party Patronage: Sponsored Mobility into the Chinese Administrative Élite, 1949-1996", American Journal of Sociology, Vol. 106, No. 5 (2001), pp. 1371-408.

52 Marc Blecher and Vivienne Shue, Tethered Deer, p. 214.
} 
pressures, the drudgery of their work and the impossibility of gaining a promotion.

\section{The Assessment System}

Party leaders, the bureaucracy and all staff, either directly or indirectly, feel the pressure of an increasingly complex system of assessments and inspections by higher levels of government. Assessments of overall government work (kaoping 考评) and individual assessments (kaohe 考核) play a crucial role in influencing what the local state does, and does not do, but what is the effect on ordinary government workers?

Different actors face different assessments. The greatest burden of the assessment system is borne by Party secretaries at both the county and township levels, as this can play a crucial role in deciding their prospects for advancement. Under this system, the Party secretaries are answerable to the Party Organization Bureau at the next level up. ${ }^{53}$ Assessments are a major tool for prefectural and provincial governments to exercise control over county leaders, and for county governments to wield power over township leaders. Both the government as a whole, and individual cadres, are assessed and ranked. There is much discussion of the need to reform the evaluation system by moving away from annual assessments, including “public satisfaction” (qunzhong manyi du 群众满意度) in the evaluations, and moving away from GDP as the main criterion. City governments in more developed provinces, such as Zhejiang, are taking the lead in this reform. ${ }^{54}$

One feature of the assessment system looms large for officials: the "one-vote veto" or “one-strike rejection" (yi piao foujue 一票否决). Under the “one-strike" system, failure to meet targets in designated key areas means that all other achievements are annulled. There are two "core tasks" in Benghai: family planning and social stability (shehui zhi'an 社会治安). This matches national priorities. County and township leaders sign lengthy responsibility contracts, involving specific targets, rewards and punishments.

In family planning work, the monetary and political rewards offered to leading cadres and family planning officers are substantial. Heads of township family planning offices are rewarded with benefits equivalent to those enjoyed by a deputy township Party secretary ( $f u$ keji 副科级) and, if they survive three annual assessments by the county Family Planning Committee and the Party Organization Bureau without receiving a warning (huang pai 黄牌), those

53 For a detailed description of the formal assessment system, see Susan Whiting, Power and Wealth in Rural China: The Political Economy of Institutional Change (Cambridge: Cambridge University Press, 2001), pp. 100-20; Maria Edin, "State Capacity and Local Agent Control".

54 See, for example, Lang Youxing, "Zhongguo ganbu kaohe zhidu zai bianlian" (The System of Cadre Annual Assessment is Changing), People's Daily, 24 March 2008. 
benefits are guaranteed until they retire. ${ }^{55}$ The pressure to raise revenue from levying fines, and the sheer volume of bureaucratic and technical tasks ${ }^{56}$ means that family planning offices must draw in resources from other agencies, leaving few funds and personnel to provide services that rural residents actually want. In Benghai, the number of agricultural technicians working in family planning offices is equal to the number working as agricultural technicians.

For social stability, the key measures are the number of grievance petitions lodged by rural residents with higher levels of government, and the occurrence of mass protest incidents. In one land-requisitioning scandal, the county government demonstrated its willingness to go to any length to suppress both the petitioners and any reporting of mass incidents. The scandal involved a failed agribusiness project that led to a hamlet losing $130 \mathrm{mu}$ ( 8.7 hectares) of rice paddy land with no compensation. Several provincial newspaper reporters and a television crew were preparing to broadcast, but a last-minute intervention with provincial-level authorities by the county Propaganda Bureau, combined with large one-off payments by the county government to the journalists (the TV reporter merited the largest bribe) and their media outlets stymied the story. Payoffs are said to be common, and media researchers report that this makes up a large portion of some journalists' incomes. ${ }^{57}$

Farmers from this hamlet still protest outside the township government offices, and once became so frustrated that they beat up an out-of-uniform police officer who had been involved in moving them off their land. When later questioned about the incident, they told the authorities he wasn't wearing a uniform, so they thought that he was a bandit. They then surrounded the township police station, and departed only after they were given 7000 yuan. In official reports, however, the county's record of social stability is maintained.

At the heart of the system is an obsession with quantification, as all assessed aspects of work are subject to a point-scoring system. Ordinary government staff in Anhui Province face an annual test that ranks their performance out of one

55 Xxian zhen jisheng fenguan lingdao yu jisheng ban zhuren kaohe renyong banfa (shixing) (The Trial Annual Assessment Method for Township Leaders in Charge of Family Planning and Directors of Family Planning Offices), issued by County X Party Organization Bureau, 2005.

56 Previously, the main technical task of family planning was female sterilization. With a shift to less drastic birth control methods (Norplant or IUDs), greater follow-up and monitoring is required. See M. Giovanna Merli, Zhenchao Qian and Herbert L. Smith, "Adaptation of a Political Bureaucracy to Economic and Institutional Change under Socialism: The Chinese State Family Planning System", Politics and Society, Vol. 32, No. 2 (2004), pp. 231-56, especially pp. 243-44.

57 David Bandurski, “China's Yellow Journalism”, Far Eastern Economic Review, Vol. 169, No. 5 (2006), pp. 49-51, and Wang Xiangwei, "Newshounds Leave Sopranos in the Shade", South China Morning Post, 9 April 2007. 
hundred points. ${ }^{58}$ These 100 points are divided up into four categories. Political integrity ( $d e$ 德) counts for 20 per cent, competence (neng 能) for 20 per cent, diligence ( $q$ in 勤) for 15 per cent, and work outcomes ( $j i$ 绩) for 45 per cent. These categories and the method of evaluation echo notions of merit and demerit that date back to imperial times. ${ }^{59}$ The four categories for personal assessments have remained unchanged since they were introduced in 1979.

Staff with no prospect of promotion mock the assessment system as unfair and useless, simply a matter of "going through the motions" (zou guochang 走过 场). Many reported that there are only two criteria for a glowing assessment: “obedience" (ting hua 听话) to one's superiors and having an influential "backstage" (houtai 后台) patron to back your promotion. Only ten to fifteen per cent of staff in any bureau should be classed as “excellent" (youxiu 优秀). Those who are evaluated as excellent for three years running are eligible for promotion but, in the eyes of most staff, only those personally favored by leading cadres receive this designation, while professional competence plays a secondary role at best. Ordinary staff with limited prospects of promotion and inadequate agency in their daily work unsurprisingly shirk their duties, a situation described as "One day of being a monk; one day of ringing a bell" (zuo yi tian heshang, zhuang yi tian zhong 做一天和尚, 撞一天钟). Staff with hopes of promotion, or who recently received a promotion, tend to defend the system.

Even staff who deride the system, however, grant that it is effective in shaping the priorities of the county government and in exerting pressure on county leaders. Personnel and finances are drawn away from other government tasks and into family planning and community policing work, which is often carried out in a coercive, campaign-style manner. As one planning official admitted, "If a task doesn't have the one-strike rejection associated with it, it means it's not important. That's how it is. If you don't go over the top, the next level up won't know. And if you really go over the top, it is effective in a way that's noticeable, at least on the surface (biaomian shang 表面上).” The assessment system is effective in shaping the behavior of local agents but, as Maria Edin notes, "the system cannot cope with more than a few state goals simultaneously, especially when those goals conflict". ${ }^{60}$

The number of tasks designated by the county as "one-strike" has expanded greatly in recent years, diminishing its efficacy. Moreover, Anhui has many examples of the limitations of administrative fiat. On 1 January 1998, the "Zero Hour Operation" (lingdian xingdong 零点行动) saw polluting paper mills along

\footnotetext{
58 "Anhui sheng jiguan, shiye danwei gongzuo renyuan lianghua ceping biaozhun biao, 2005" (Table of Quantifiable Criteria for Administrative and Service Staff in Anhui Province, 2005).

59 Cynthia Joanne Brokaw, The Ledgers of Merit and Demerit: Social Change and Moral Order in Late Imperial China (Princeton: Princeton University Press, 1991).

60 Maria Edin, "State Capacity and Local Agent Control”, p. 51.
} 
the Huai River basin raided under cover of darkness and closed down. Local government leaders faced the one-strike policy for breaches of environmental protection regulations, but the mills gradually reopened, as local governments were dependent upon revenue from the mills. ${ }^{61}$ For a task to be vigorously and consistently pursued by local leaders it must not only be assessable by higher levels; it must also provide financial benefit to the county government, individual cadres and the intermediaries who make up the "shadow state". One government task fits all of the above criteria, and has led to many conflicts of interest in recent years: attracting investment (zhao shang yin zi 招商引资).

\section{Attracting Investment: The Schizophrenia of Market-Leninism}

Chinese academics have expressed concern that attracting investment has been incorporated into the annual assessments of local governments and officials. ${ }^{62}$ Taking their cue from Zhejiang and Jiangsu, since 2005 the Anhui provincial government has exerted pressure on county leaders to attract private and government investment. ${ }^{63}$ In Benghai, the leaders of every county agency and every township government are set quotas for the amount of investment they should attract each year, with wealthier bureaus additionally facing targets for the number of projects attracted to the County's Eco-Industrial Park. ${ }^{64}$ Entirely inappropriate agencies are not exempt from these strictures. Table 4 is an abbreviated list of targets set for attracting investment in a neighboring county (68 different county agencies were assigned investment quotas).

61 Elizabeth C. Economy, The River Runs Black: The Environmental Challenge to China's Future (Ithaca: Cornell University Press, 2004), Chapter 1.

62 Wu Licai and Zhu Hongxuan, "Xiangzhen gaige: xiangzhen ganbu de suo si suo xiang — dui Hubei sheng xiangzhen ganbu de wenjuan diaocha" (Township Reform: What Township Cadres Think-A Survey of Hubei Province), Zhongguo nongcun jingji (China Rural Economy), No. 11 (2005), pp. 61-67; Yu Meng, "Cong gong, jian, fa 'gai hang' zhao shang yin zi shuo qi" (Musing on Why My Classmates in the Police and Judiciary Are Seeking Investment), People's Daily Online, 16 May 2004 (accessed 13 September 2006; no longer available on the People's Daily site, but the article can still be found on Sina's finance page at http://finance.sina.com.cn/roll/20040518/0356764150.shtml, accessed on 18 May 2009). A People's Daily reporter was contacted by former classmates seeking investment. He was told, "There's no bottom line. Land, tax, everything can be negotiated ... good projects are hard to attract, as everyone else is offering preferential deals, but energy-intensive, heavilypolluting industries are easier to bring in. The projects no one wants, we'll take them all." Author's interviews, Anhui Academy of Social Sciences, November 2008.

64 One local reporter visited Siyang County in southern Jiangsu to investigate their "name and shame" policy of publicizing the "worst work unit" and "worst cadre". He found that rankings were largely based on tasks related to attracting investment, and noted a large number of incomplete projects and deserted government offices. He was assured by a local brothel owner that "the county leadership is going all out to attract investment, so the police never come here on inspections. So it's very safe! Relax!" See Tao Jianqun, "Siyang, ni weihe pa caifang?" (Siyang, Why Are You Afraid of Reporters?), Shidai chao (Contemporary Tide), No. 8 (2003), pp. 12-13. 
Table 4: Point-Scoring Tasks for Attracting Investment, 2005

\begin{tabular}{|l|l|l|l|}
\hline Agency & Foreign (US\$) & $\begin{array}{l}\text { Domestic } \\
\text { (RMB) }\end{array}$ & $\begin{array}{l}\text { Projects for } \\
\text { Industrial } \\
\text { Park }\end{array}$ \\
\hline Investment (招商局) & $1,000,000$ & $10,000,000$ & 2 \\
\hline $\begin{array}{l}\text { Industry and Commerce (工商 } \\
\text { 联) }\end{array}$ & 500,000 & $5,000,000$ & 1 \\
\hline Finance (财政局) & 100,000 & $1,500,000$ & 1 \\
\hline Police (公安局) & 100,000 & $1,500,000$ & 1 \\
\hline Organization (组织部) & 100,000 & $1,500,000$ & 1 \\
\hline Family Planning (计生委) & 50,000 & $1,000,000$ & 0 \\
\hline Meteorology (气象局) & 50,000 & $1,000,000$ & 0 \\
\hline Bank of China (中国银行) & 50,000 & $1,000,000$ & 0 \\
\hline
\end{tabular}

Source: Neighboring County Government Documents, 2006

Investments (when successful) boost government coffers, and individuals who succeed in attracting investment are paid a commission by the county government. The rate is currently set at 0.5 per cent of the value of fixed investment of each project. To spur competition, the successes of individual cadres, bureaus and township governments in attracting projects are painted prominently on walls throughout the county government compound. New projects are also a boon to the shadow state, from construction contractors to restaurant owners.

The establishment of the Benghai Eco-Industrial Park provides an insight into the lack of selectivity applied by county leaders in attracting investment. The initial site was slightly more than $200 \mathrm{mu}$ (13.3 hectares) of rice paddy, affecting two hamlets. The site was meant to accommodate a five-star hotel, to be built with backing from a "Taiwanese" investor. No one thought to ask why any businessman would want to build a resort in a remote county in central China. The land was duly cleared, the peasants evicted, and the investor spent a month familiarizing himself with the banquet menus, gambling halls and saunas of Benghai. ${ }^{65}$ Eventually, he was found to hail from Fuyang, in northern Anhui, and did not even possess an urban residence permit. With the land now unfit for farming, the county leadership immediately declared the area an Eco-Industrial Park. It has since been upgraded to a provincial-level development zone, expanding to an area of 15 square kilometers.

Another incident illustrates how the political incentives of bureaucratically imposed targets can lead local cadres to harm local businesses. The county Propaganda Bureau had succeeded in matching an investor from Fujian with a privately-run paper mill in Benghai. The business proposal was to produce environmentally-friendly food packaging for the Japanese market (the Fujian

65 This is known as the "green card" ( $l \ddot{u} k a$ 绿卡), offered by county and township leaders to potential investors, including the author, who respectfully declined. 
man sported a fake Japanese passport, and thus counted as an "overseas investor"). After trust-building exercises in local saunas, he signed off on half the sum required for upgrading the paper mill, and provided the mill owners with a list of suppliers who could provide them with the technology. However, the investor and the listed suppliers were the same entity, and the paper mill was tricked into paying well over market value for the equipment, because they believed their "partner" was paying half of this amount. Packaging was produced, but with their partner suddenly not returning calls, no market could be found for the expensive packaging, resulting in losses running into millions of yuan.

As the county's success in attracting an overseas investor had already been reported to the province, and the political credit had been claimed by the county leadership, the police were reluctant to investigate, and for half a year stymied all efforts to recover the funds. Eventually the mill owner, with the aid of friends in the provincial government, managed to induce the provincial police bureau to exert pressure on the county police department. The investor was captured by the county police, who promised to release him if he paid into the police department's bank account the sum invested by the paper mill. They then released the "investor" into the waiting arms of a neighboring county's police service, where he had perpetrated the same scam. The amount bilked nationwide exceeded 300 million yuan, but because in each case the county and prefectural leadership had been duped, none of the other counties or prefectures had previously attempted to bring the investor to book. ${ }^{66}$

The county cadres' short time-horizons and lack of means (or inclination) to assess the potential profitability of investments recall Susan Whiting's account of the impact of a quota system on local cadres in wealthy counties seeking foreign joint venture projects during the early 1990s. ${ }^{67}$ However, in the current quota-driven system, political points are scored for bringing in new investment every year, leading to a cycle which local officials describe as "one firm comes in, another goes bust" (zhao yi ge, kua yi ge 找一个, 跨一个). Many local enterprise managers collude with officials to register their businesses as non-local, thus qualifying as "new" investment. Although outcomes are often less than ideal, the behavior of county cadres is rational, within the bounds of the assessment system.

\section{Retrieving the Poverty Hat}

Nor is it simply a question of grasping local cadres thwarting the will of the central government. The need to involve central and provincial levels of government in quota-driven duplicity is illustrated by Benghai County's

\footnotetext{
66 The mill owner's saga did not end there - before the police would release the money, they demanded that he pay a 100,000-yuan “cracking-the-case fee" (po'an fei 破案费). As no such fee existed anywhere in government financial regulations, 80,000 yuan was paid in kind: the Police Department received a new vehicle.

67 Susan Whiting, Power and Wealth in Rural China, pp. 110-16; see also Kevin O'Brien and Lianjiang Li, "Selective Policy Implementation", pp. 171-76.
} 
reluctance to lose its "poverty hat". Despite relatively healthy GDP and government revenue figures, Benghai was designated in 1986 as an impoverished county (guojia ji pinkun xian 国家级贫困县). More than two decades later, it remains one of China's 592 poverty counties, with the number of impoverished residents officially calculated to be just over five per cent of the population. Both county and provincial officials privately concede that it should have lost the "hat" some time ago. During the mid-1990s, it was briefly removed in order to further the prospects of county leaders, but financial benefits to the formal and shadow state-subsidized microfinance (invariably benefiting local élites) ${ }^{68}$ and national infrastructure projects - were too valuable to forgo. Through networks in Beijing, the poverty designation was retrieved, and two large-scale international aid projects were attracted to the county. ${ }^{69}$ After obtaining these projects, removing the "hat" would have placed the international donors and the central government in an awkward position so, despite sustained economic growth, the hat remains securely in place. ${ }^{70}$

The acquisition of poverty status illustrates a common theme in local officials' explanations of corruption: it persists with the blessing and encouragement of higher levels. A common refrain was "when the top beam is set aslant, the lower ones will be crooked" (shangliang bu zheng xialiang wai 上 梁不正下梁歪). Many informants pointed to the proliferation of local government offices opening in Beijing (zhu jing ban 驻京办) and other cities (Benghai County had offices in seven). ${ }^{71}$ As one local businessman asked, "What do you think these offices do? Hand out brochures? The money goes up, and then the money comes down. It's like a huge school of fish, with each one dining out on the next smallest one in the chain, while the innumerable small fish at the bottom [county and township governments] desperately seek ways to nibble at the big fish [central government]." ${ }^{, 72}$

68 See Kellee S. Tsai, Back-Alley Banking: Private Entrepreneurs in China (Ithaca: Cornell University Press, 2002), pp. 232-38.

69 Benghai is far from unique. Wuwei County, which consistently ranks among Anhui's ten wealthiest counties, retains its poverty hat to this day. These irregularities have led to a shift towards targeting poor villages, rather than the designated counties. Nick Young, “Government Embraces 'Participation', Pledges More Poverty Funds and Better Targeting”, Beijing: China Development Brief, 2005.

70 Anhui's provincial governor, Wang Jinshan, conceded that county-level statistics on peasants' incomes were falsified to keep their "poverty hats" in place. Irene Wang, "Central Edicts 'Not Right for All Regions", South China Morning Post, 24 April 2006. The arbitrary nature of poor county designations has been noted by previous researchers. See Albert Park and Sangui Wang, "China's Poverty Statistics", China Economic Review, Vol. 12, No. 4 (2001), pp. 396-97.

71 Beijing boasts over 5000 such lobbying houses, representing local industries and governments. Tao Ran, personal communication, October 2008.

72 I am unaware of any academic studies, but a trilogy of novels has brought these offices considerable popular attention. See Wang Xiaofang, Zhu jing ban zhuren (Local Government Lobbyist in Beijing) (Beijing: Zuojia Chubanshe, 2008). 
Regardless of what quotas are written into the annual assessments, this money-driven and output-obsessed audit system causes leading cadres and departments to look upwards to their immediate superiors, who can provide financial and political rewards, rather than downwards to the rural residents whom they are supposed to serve under the principles laid down in the central government's vision for "building a new socialist countryside". 73

\section{The New Socialist Countryside}

County Party officials spoke of the New Socialist Countryside Program with a mixture of hope and fear. Hope, because the Program offered the prospect of substantial infrastructure investment in rural areas, potentially bringing to an end more than five decades of rural areas being squeezed to prop up urban-based industrial development. Also, local governments have been struggling since the abolition of agricultural taxes in 2005. With insufficient revenue passed on from higher levels to make up for the local loss of tax revenue, village and township governments are selling off land to developers just to feed their staff. The main sources of off-budgetary funds have gradually shifted from enterprise fees, to highway fees, to land transfer fees (tudi churang jin 土地出让金) and sales of government assets. Nationwide, the funds raised by land transfers were estimated at 615 billion yuan in 2004. By comparison, fiscal transfers by the central government to lower levels of government amounted to 1,041 billion yuan in the same year. ${ }^{74}$

Fear, because they could foresee an extra financial burden. They have already seen their share of worthy but under-funded central government programs. When asked about the Program, many recalled the compulsory education scheme launched in the 1990s with the noble aim of ensuring that every child received nine years of schooling ( $p u$ jiu 普九). It also saddled many township and village governments with debts that they will never pay off. Cadres made one thing clear-another large central government campaign meant business as usual. Communist traditions of showcasing, output obsession, betting on the strong, and

73 For more detail on the development of output-obsessed audit cultures in local government, see Zhao Shukai, "Rural Governance in the Midst of Underfunding, Deception, and Mistrust”, Vol. 39, Chinese Sociology and Anthropology, edited by Andrew Kipnis and Graeme Smith (2007), pp. 64-73.

74 See Susan Whiting, "Central-Local Fiscal Relations in China", in China Policy Series (New York: National Committee on US-China Relations, 2006), pp. 8-11, and Zhou Feidan, "Sheng cai you dao: Tudi kaifa he zhuanrang zhong de zhengfu yu nongmin" (Playing the Market: Government and Peasants in Land Development and Transfer), Shehuixue yanjiu (Sociology Research), No. 1 (2007), pp. 49-82. By 2008, land transfers were estimated to be worth 1.2 trillion yuan, and there were calls for the use of these funds to be made public, amid concerns that they were fueling local government corruption. See Wu Ruidong, "Wanyi tudi churang jin yongtu ying xiang gongzhong gongkai" (The Use of One Trillion Yuan in Land Transfer Fees Should Be Public), People's Daily, 23 April 2008. 
campaign-style governance were back in vogue, and influencing patterns of selective policy implementation.

Explaining the cyclical nature of government campaigns, one official ground his fist into his palm with a twisting motion, saying:

This is how it always goes. On the surface, you see a great deal of activity and movement. But it just stays on the surface. Whenever a new government direction comes along, firecrackers are let off as new offices are established, signs and banners are painted, the inflatable memorial arch goes up over there [indicating the road in front of the county government office], the propaganda van drives around, speeches are written, meetings are convened, and slogans are invented. But it's all on the surface. It slowly fades away, until the next campaign starts up.

Local officials' pronouncements and implementation of the Program suggested that, while tangible benefits were being delivered to rural residents - particularly the construction of an extensive network of paved roads - it has, perhaps unintentionally, reinforced a campaign-style approach to governance, with rhetoric reminiscent of the Great Leap Forward. In the 2007 Benghai county Work Report on Building the New Socialist Countryside, cadres are exhorted to "lay the groundwork through the whole county, seek breakthroughs in the model villages", to "transform social traditions" and "to establish healthy customs for weddings and funerals".

An obsession with outputs and quantification is evident. Each model village is to train three to five specialist households, establish at least one farmers' specialized cooperative, and develop one new specialty product. Rural incomes are to be raised by 15 per cent annually, 30 to 50 farmers from each village to be retrained by local companies and training agencies, 20 per cent of the "agricultural structure" must be adjusted this year, and each village must have at least $200 \mathrm{mu}$ planted to a specialty crop, of which at least $50 \mathrm{mu}$ must be connected together. Many economists argue that output obsession is the main impediment to improving China's microeconomic performance. ${ }^{75}$ Obsession with outputs has fed patterns of selective policy implementation. Measurable, tangible aspects of the program, such as road-building, were more likely to be prioritized by county leaders than intangible objectives, such as supporting democratic rural governance.

"Betting on the strong" is also evident. Designated model villages were required to have "relatively good economic conditions". The 16 model villages (one for each township) are ranked as provincial-level, prefectural-level or county-level demonstration villages under the Program. The wealthier townships have the highest-ranked model villages, and the five model villages designated as the lowest priority for funding (county-level, rather than provincial- or citylevel model villages) are located in the five poorest, most remote townships.

75 See especially Huang Yasheng, "The Microeconomic Rise of India", Far Eastern Economic Review, Vol. 169, No. 2 (2006), pp. 31-33. 
Directing resources towards "model villages" reinforces a traditional Communist approach to rural governance: showcasing, where money is put into projects that are shown off to visiting officials. This is one of the reasons that, of the 16 model villages, three are located in the township seat itself. Although coverage of sealed roads in Benghai County is limited, all 16 model villages share one characteristic: they may be reached by one. All interviewees admitted this was one of the primary considerations in choosing model villages. Higher-level delegations do not enjoy travelling on dirt roads, and for them even to know about poorly maintained roads would itself reflect poorly on the county leadership.

The Leninist spirit of the new socialist countryside campaign was captured by deputy county head Zhang, in one of his final speeches before being detained for taking kickbacks from construction companies:

We have to ramp up construction. This year's plan was 270 kilometers of bituminized road, but we've only completed 30 per cent. We don't have enough finished projects to show, so let's speed up. The prefectural government will shortly inspect all rural construction projects, and provincial government leaders will soon be here. There's less than a third of the year left. Things haven't gone smoothly, but we must seize our chance and surpass the plan (ganchao jindu 赶超进度)! We must be flexible in our methods, with administrative fiat (xingzheng ganyu 行政干预) as support ... After this round of rural planning and construction, wherever you go in Benghai, you should see our vision for the new countryside!

\section{Discussion}

Rural governance still relies on "all-out" campaigns but, rather than being directed at the whole rural population, it is now a case of cadres mobilizing cadres. Output figures and targets are said to demonstrate "scientific management techniques", in a strange fusion of Maoist rhetoric and Western management studies doublespeak, but most of the quantification in government work reports and annual assessments is meaningless. As cadres admit, the numbers in reports and assessments, whether they relate to farmers' incomes, the length of sealed road in the county or the number of farmers' associations established, are whatever they want to say they are. There is no science. It is, as one respondent noted, “a game on paper” (wenzi youxi 文字游戏).

In Benghai County, the Party trumps government agencies in the allocation of resources, tasks and personnel. Collusion between Party leaders, their personal assistants, and their friends and relatives in the local business community has led to the emergence of a "shadow state" dealing in government contracts, projects and the ubiquitous trade in government posts. It was also known that all township Party secretaries and most heads of county bureaus had paid bribes to secure their positions, eroding the respect of staff for their superiors (the vast majority of ordinary staff had "shown their appreciation" to obtain their jobs, but the sums involved in such transactions were considerably less). There exists a clear and growing divide between different types of cadres 
within the county government, with service cadres often holding the administrative cadres in contempt for being less technically competent.

The continuity of rural political structures partly explains the prevalence of personalized rule and campaign-style governance, but collective norms regarding the appropriate manner in which the local state ought to function are also crucial to their persistence in the face of attempts to move towards service-oriented government. These norms are particularly ingrained among administrative cadres. As one county official remarked on hearing of a drive to reduce the number of meetings and documents, "The one thing the Party has taught us is how to hold meetings and issue documents. If they take that away, what will we do?" Documents on reducing the number of documents were duly issued, and rounds of meetings were held to discuss reducing the number of meetings.

Personalized rule coupled to bureaucratism, output obsession and a shortterm campaign approach to rural administration is routinized in Benghai County. These routines are reinforced by historical continuities in rural political structures and by the Party's strategies of formal and informal control. Growing opportunities for personal enrichment are found through a shadow state which "spills into the lanes surrounding state offices and into the private domestic space of officials' residences", ${ }^{76}$ encouraging local leaders to maintain the status quo. Politics are firmly in command, and doing very nicely, thank you. Without citizen participation in cadre selection and assessment, this is unlikely to change.

The result is a local state which is effective in completing a selected range of tasks, particularly those tasks which bring about a confluence between the political imperatives of the annual assessments, the pressure to raise revenue and the prospect of personal financial gain. However, continued emphasis on quantifiable results, rather than process, mean that the actions of county government often contradict central government rhetoric, the development ideals of its own staff and the interests of rural residents.

76 Barbara Harriss-White, India Working, p. 89. 